\title{
Cikkismertetés: Tanuljunk együtt, hogy csökkenjen az iskolai zaklatás és agresszió!
}

\author{
Article review: Learning together to decrease bullying and \\ agression in schools!
}

Ismertető: $\quad$ Járomi Éva $\square$

Állami Egészségügyi Ellátó Központ

Ismertetett cikk: Bonell C, Allen E, Warren E, et al. Effects of the Learning Together intervention on bullying and aggression in English secondary schools (INCLUSIVE): a cluster randomised controlled trial. Lancet. 2018 Dec 8;392(10163):2452-2464.

doi: 10.1016/S0140-6736(18)31782-3

Beküldve: $\quad$ 2019. 05. 07.

doi: $\quad$ 10.24365/ef.v60i5.467

Kulcsszavak: iskolai zaklatás; agresszió; klaszter-randomizált kontrollált vizsgálat

Keywords: school bullying; agression; cluster randomized controlled trial

\section{HÁTTÉR}

A gyermekek és fiatalok körében terjedő zaklatás (bullying), agresszió és erőszak napjainkban a komoly következményekkel járó népegészségügyi problémák közé sorolható. Az Egészségügyi Világszervezet (World Health Organization, WHO) meghatározása szerint a bántalmazás a fizikai vagy pszichológiai erő saját magunkkal vagy másokkal szembeni szándékos alkalmazása. Az agresszió ellenséges vagy romboló magatartást foglal magában, és a zaklatás vagy az erőszak megszokott része. A zaklatás a brit fiatalok körében elterjedtebb, mint a többi nyugat-európai országban, és jellemzően internetes zaklatás (cyberbullying) formájában valósul meg. A gyermekkorban átélt zaklatás és erőszak többszörös fizikai és lelki egészséggel kapcsolatos károkat okoz gyermek- és felnőttkorban egyaránt, amely akár alacsonyabb iskolai teljesítményben is megnyilvánulhat. A zaklatás megelőzése nemzetközi szinten a népegészségügyi és a köznevelési rendszer fő prioritásai közé tartozik, az iskolák pedig a fiatalok mentális egészségének és jóllétének javítására irányuló kezdeményezések kulcsfontosságú színterét képezik. A kihívás abban rejlik, hogy ezeket az egymással összefüggő viselkedésformákat egyetlen koherens beavatkozással kezeljék, ahelyett, hogy többféle beavatkozással terhelnék túl az amúgy is elfoglalt pedagógusokat.

A jelen közleményben bemutatott cikk szerzői egy olyan iskolai beavatkozást dolgoztak és próbáltak ki, amely a zaklatás és az egyéb egészségkockázatok csökkentését célzó három legígéretesebb megközelítést veszi alapul. Az első megközelítés a teljes iskolára irányuló beavatkozás, amelynek célja az oktatáspolitika és az iskolarendszer átfogó módosítása. A második megközelítés egy olyan resztoratív gyakorlatoni alapul, amelynek célja az

\footnotetext{
¡ „A resztoratív, más néven helyreálító vagy jóvátételi szemlélet lényege az, hogy a normasértést nem elsősorban szabályszegésként, hanem a résztvevők közötti konfliktusként értelmezi. Célja az, hogy a konfliktus következtében kialakult károkat úgy állítsa helyre, hogy a kárt okozó személy aktívan felelősséget vállaljon tettéért, és valamilyen jóvátételt ajánljon fel a megsértett személynek és a közösségnek. A konfliktus feloldásának folyamatában tehát a sértett, az elkövető és a közösség szempontjai és szükségletei egyaránt érvényesülnek." Kalmár M, Nagy É. Resztoratív technikák egy iskola életében. Új Pedagógiai Szemle 2012;7-8. p. 144.
} 
iskolai személyzet és a tanulók, illetve a diákok egymás közötti konfliktusainak megelőzése vagy megoldása a további ártalmak elkerülése érdekében. A harmadik megközelítés pedig a szociális és érzelmi nevelés, melynek eredményeként a fiatalok elsajátíthatják a társas együttéléshez szükséges készségeket.

A fenti megközelítések ötvözésével fejlesztették ki a szerzők 2014-ben az „együtt tanulás” elnevezésű beavatkozást, amelynek célja az iskolai környezet megváltoztatása a zaklatás és az agresszió csökkentése, valamint a diákok egészségének és jóllétének elősegítése érdekében.

\section{MÓDSZER}

Klaszter-randomizált kontrollált vizsgálat keretében, folyamatértékeléssel és gazdasági elemzéssel kiegészített vizsgálatra került sor 2014 és 2017 között 40 délkelet-angliai középiskolában. Az iskolák 7. évfolyamos (11-12 éves) tanulói vettek részt a kiinduló vizsgálatban, melyet 24 és 36 hónappal később újra megismételtek (10. évfolyam vége; 14-15 évesek).

A beavatkozás célja az volt, hogy lehetővé tegye a fiatalok számára az egészségesebb magatartás választását autonómiájuk, motivációjuk és érvelési képességük fejlesztésével. Mindezt az iskola iránti elköteleződés növelésével segítették elő, melynek eszközei a tanulók közötti, illetve a diákok és tanárok közötti kapcsolatok javítása, az iskolai oktatás és a szélesebb körű tanulói készségfejlesztés, valamint az iskolai gyakorlatokra és a szervezett tanulói igényekre történő összpontosítás voltak.

A kontrollcsoportba véletlenszerúen kiválasztott iskolák megszokott gyakorlatukat folytatták, és semmilyen további beavatkozást nem kaptak. A kísérleti (intervenciós) és a kontrollkörnyezetben egyaránt megvizsgálták a zaklatásra, a fegyelemre, valamint a szociális és érzelmi nevelésre vonatkozó gyakorlatokat, valamint a tanulók részvételét az iskolai döntéshozásban, majd a kísérleti csoportban történt beavatkozás után megvizsgálták az annak hatására bekövetkezett változásokat.

\section{EREDMÉNYEK}

40 iskola vett részt a vizsgálatban (mindkét csoportban 20 iskola). A 71217 . osztályos tanulóból 6667 $(93,6 \%)$ vett részt az első kiinduló felmérésben, majd 36 hónappal később 7154 főből 5960 (83,3\%). 36 hónap elteltével az átlagos zaklatási pontszám (Gatehouse Bullying Score, GBS) ii a kontrollcsoportban 0,34 (SD 0,02) volt, szemben az intervenciós csoport 0,29-es (SD 0,02) pontszámával. Az átlagos iskolai helytelen viselkedés pontszám (Edinburgh Study of Youth Transitions and Crime, ESYTC)ii a kontrollcsoportban a 36. hónap végére 4,33 (SD $0,20)$ volt, szemben az intervenciós csoport 4,04-es (SD 0,21) értékével, a csoportok közötti különbség tehát nem szignifikáns (korrigált különbség -0,13, 95\% konfidencia intervallum - 0,4-tól 0,18-ig, korrigált hatásméret $-0,03)$. A beavatkozás tanulónként 58 angol font többletköltséget jelentett az abban részesülő iskolák számára.

\section{KÖVETKEZTETÉSEK}

A beavatkozás hatással volt a teljes mintára, beleértve azokat az iskolákat is, amelyeknek a zaklatással és agresszióval kapcsolatos kiinduló értékei magasabbak voltak. A diákok által jelentett agreszsziós esetek összesített száma nem csökkent, azonban a program másodlagos hatásai jelentősek voltak: a pszichológiai funkciók, a jóllét és az életminőség javultak, a rendőrségi ügyek száma, a dohányzás, az alkohol- és a kábítószer-használat csökkent. A beavatkozás korlátozta a meglévő zaklatási eseteket és az agressziót (másodlagos megelőzés), valamint megelőzte az újabb zaklatási és agressziós események megjelenését (elsődleges megelőzés). Az "együtt tanulás” beavatkozás nagyobb hatást gyakorolt a fiúkra, mint a lányokra a másodlagos pszichológiai és viselkedési kimenetek tekintetében, az elsődleges kimenetek esetében

\footnotetext{
ii 12 itemből álló validált önkitöltős mérőeszköz, amely a szemtől-szemben és/vagy az interneten keresztül történő ugratásnak, gúnyolásnak, pletykának, mellőzésnek és tényleges fizikai fenyegetésnek vagy bántalmazásnak az elmúlt 3 hónapban való kitettséget méri.

iii Edinburgh Study of Youth Transitions and Crime - Edinburgh kutatás, az Ifjúsági Átmenetről és Bűnözésről. Az ESYTC kutatásban használt iskolai helytelen viselkedés alskála 13 itemből áll és a diákok és tanárok felé irányuló agresszió önbevallásán alapul.
} 
azonban nem tapasztaltak nemi különbségeket. A trénerek, a facilitátorok és az iskolai alkalmazottak költsége az intervenciós csoportokban a vizsgált 3 év alatt tanulónként további 47-58 angol font volt, a kontrolliskolák költségeivel összehasonlítva. A kutatók azt találták, hogy az intervenció zaklatásra gyakorolt hatása a 36. hónapban mérhető volt (az előzetes hipotézisnek megfelelően), a 24. hónapban azonban még nem, és ugyanez a hatásmechanizmus vonatkozott a legtöbb másodlagos kimenetre is.

$\mathrm{Az}$ ismertetett vizsgálat is alátámasztja azt, hogy a teljes iskolára irányuló megközelítések hatékonyak a zaklatás és az agresszió megelőzésében, valamint a tanulók egészségének fejlesztésében és számos további pozitív hatással bírnak a magas, közepes és alacsony jövedelmű társadalmi közeg- ben is. Az „együtt tanulás” ezen kívül lehetőséget nyújt a viselkedés és az egészség széles körü javítására a középiskolákban, a vizsgálat eredményei pedig hozzájárulnak a középiskolai resztoratív megközelítések továbbfejlesztéséhez.

Manapság, amikor a fiatalok mentális egészsége jelentős nemzetközi népegészségügyi aggodalomra ad okot, néhány ország, mint például az Egyesült Királyság és Ausztrália az iskolákat nevezték meg a mentális egészség javításának kulcsszereplőjeként. A tanulók mentális egészségének és jóllétének előmozdításához a teljes iskolai környezet megváltoztatása az egyik leghatékonyabb mód, amely további hatást gyakorol a serdülőkorúakat érintő egyéb egészségkárosodásokra is, mivel lehetőséget ad a populációs kockázatok módosítására is.

\section{TANULSÁGOK A HAZAI SZAKEMBEREK SZÁMÁRA}

Az ismertetett tanulmányban megfogalmazott megállapítások fontosak a népegészségügyi szakpolitika szempontjából, mivel a fenti program azon meglehetősen alacsony költségű beavatkozások egyike, amely népegészségügyi szempontból fontos, pozitív következményekkel jár.

Hazánkban az online és fizikai zaklatás szintén egyre növekvő probléma, megelőzésének és csökkentésének eredményessége több ágazat (pl. egészségügy, szociális, köznevelés) bevonásával érhető el.

A társadalmi egyenlőtlenségek és feszültségek csökkentése elsődleges az iskolai erőszak és a kortársbántalmazás formáinak megelőzésében. Ezek a feszültségek ugyanis begyűrüznek a gyermekek elsődleges szocializációs színterébe, a családba és mikrokörnyezetébe. A multiszektoriális, több szinten történő együttmúködés keretében a gyermekek lelki egészségének, kiegyensúlyozottságának megerősítése, és a családok körülményeinek és a lelki egészséggel kapcsolatos ismereteinek növelése ezért kiemelten fontos. 